\section{Erwin Musdah}

Dosen Luar Biasa Universitas

Muhammadiyah Makasar

Email: erwinmusdah@gmail.com

\section{Rahmawati Husein}

Magister IImu Pemerintahan Universitas Muhammadiyah Yogyakarta

Email: amahusein@yahoo.com

http://dx.doi.org/10.18196/

igpp.2014.0021

\section{Analisis Mitigasi Nonstruktural Bencana Banjir Luapan Danau Tempe}

\begin{abstract}
This research aimed to know how mitigasi non-structural Tempe lake overflow flood disaster through ordering room and to express cooperations inter-government regency in mitigasi non-structural Tempe lake overflow flood disaster through ordering room. This research is descriptive qualitative research with triangulation method data collection. It so happens data analysis method used namely descriptive qualitative data analysis method. Result research indicate that mitigasi non-structural effort Tempe lake overflow flood disaster through ordering room has look in some article in lay-out plan regional policy area in Sidenreng Rappang, Soppeng and Wajo regency although inside regulation that is same still found articles that are potentially detain that effort. Besides, this research found that do not have cooperation among each one government regency in mitigasi non-structural through ordering room.

Keyword: disaster mitigation, ordering room, disaster flood, development area.
\end{abstract}

\begin{abstract}
ABSTRAK
Penelitian ini bertujuan untuk mengetahui bagaimana mitigasi nonstruktural bencana banjir luapan Danau Tempe melalui penataan ruang dan untuk mengungkapkan kerjasama antar pemerintah kabupaten dalam mitigasi nonstruktural bencana banjir luapan Danau Tempe melalui penataan ruang. Penelitian ini merupakan penelitian deskriptif kualitatif dengan metode pengumpulan data triangulasi. Adapun metode analisis data yang digunakan yaitu metode analisis data deskriptif kualitatif. Hasil penelitian menunjukkan bahwa upaya mitigasi nonstruktural bencana banjir luapan Danau Tempe melalui penataan ruang telah terlihat pada beberapa pasal dalam peraturan daerah rencana tata ruang wilayah di Kabupaten Sidenreng Rappang, Soppeng dan Wajo meskipun dalam peraturan yang sama masih ditemukan pasal-pasal yang berpotensi menghambat upaya tersebut. Selain itu, penelitian ini ditemukan bahwa belum ada kerjasama antara masing-masing pemerintah kabupaten dalam mitigasi nonstruktural melalui penataan ruang.

Kata kunci: mitigasi bencana, penataan ruang, bencana banjir, pengembangan wilayah
\end{abstract}

\title{
PENDAHULUAN
}

Posisi Indonesia yang berada di daerah rawan bencana menyebabkan sering terjadinya berbagai macam bencana. Diantara semua kejadian bencana yang terjadi di Indonesia, bencana banjir merupakan bencana dengan intensitas kejadian paling tinggi. Dari data yang dirilis oleh Data dan Informasi Bencana Indonesia BNPB 
(2013) diperoleh informasi bahwa mulai dari tahun 1815 sampai tahun 2013, bencana banjir tercatat dengan intensitas kejadian 4.261 kejadian atau 38\% dari seluruh jenis bencana yang ada. Kejadian banjir dua kali lebih banyak dari kejadian tanah longsor dengan intensitas 2.031 (18\%) kejadian dan angin puting beliung dengan 2.021 (18\%) kejadian. Tahun 1815-2013, bencana banjir menempati urutan ketiga korban bencana paling banyak setelah gempa bumi disertai tsunami dan letusan gunung api.

Salah satu daerah yang rawan banjir adalah daerah di sekitar Danau Tempe. Danau Tempe berada di tiga kabupaten yaitu Kabupaten Wajo, Sidenreng Rappang dan Soppeng Sulawesi Selatan. Terdapat lima sungai besar yang bermuara di Danau Tempe. Masingmasing sungai membawa erosi dan sedimen ke Danau Tempe dengan perkirakan penumpukan sedimentasi 3-4 cm setiap tahun (Nurkin 1994 dalam Dewi 2001:2). Akibat dari sedimentasi pendangkalan pada dasar Danau. Air yang tidak mampu lagi ditampung oleh Danau Tempe akhirnya meluap menjangkau pemukiman dan lahan warga. Adapun dampaknya dapat dilihat pada tabel berikut:

TABEL 1. DATA DAMPAK BENCANA BANJIR TAHUN 2013

\begin{tabular}{llll}
\hline Kabupaten & Kecamatan & Rumah Terendam & Lahan Pertanian Rusak (Ha) \\
\hline Wajo & Tempe & 5.527 & - \\
& Belawa & 3.794 & 2.825 \\
& Tanasitolo & 2.082 & 223 \\
\multirow{4}{*}{ Soppeng } & Sabbangparu & 4.184 & - \\
& Donri-Donri & - & 617 \\
Sidenreng Rappang & Marioriawa & - & 625 \\
\hline
\end{tabular}

Sumber: Dinsos Wajo, Badan Kesbanglinmas Soppeng, Kelurahan WetteE Kec. Pancalautang Sidenreng Rappang 2013

Bencana banjir masih akan terus berulang tanpa adanya upaya penanggulangan bencana yang baik. Dalam sistem penanggulangan bencana, siklus penanggulangan bencana terdiri dari mitigasi, kesiapsiagaan, tanggap darurat dan pemulihan (Nurjannah dkk. 2007; Priambodo 2009). Untuk mengurangi atau mencegah dampak 
bencana banjir maka upaya yang paling penting dilakukan adalah mitigasi bencana dan kesiapsiagaan. Mitigasi bencana mencakup upaya pencegahan dan pengurangan resiko bencana (Priambodo 2009). Dalam penanggulangan bencana, mitigasi bencana memegang peranan yang sangat vital. Jika ancaman bahaya berhasil dicegah maka tidak perlu lagi ada kesiapsiagaan, tanggap darurat ataupun pemulihan. Namun demikian, tidak semua ancaman bahaya dapat dicegah sehingga upaya mitigasi lain yang dapat dilakukan adalah mengurangi resiko bencana. Jika upaya pengurangan resiko bencana berhasil dilakukan maka, upaya kesiapsiagaan, tanggap darurat, dan pemulihan tidak lagi membutuhkan tenaga dan biaya yang lebih besar.

Mitigasi bencana itu sendiri terdiri dari dua kategori yaitu mitigasi struktural dan mitigasi nonstruktural. Mitigasi struktural yaitu upaya pengurangan resiko bencana melalui pembangunan fisik seperti pembangunan bendungan, tanggul dll. Mitigasi nonstruktural yaitu upaya pengurangan resiko bencana melalui aktivitas nonfisik seperti pendidikan kebencanaan, penataan kota, dll.(Benson \& Twigg 2007). Pada penelitian ini dibatasi pada mitigasi nonstruktural. Mitigasi nonstruktural ini dipilih karena kajian tersebut lebih sesuai dengan bidang kajian ilmu sosial. Sebaliknya, kajian mitigasi struktural lebih tepat dikaji oleh ilmu eksakta. Mengingat luasnya bidang kajian mitigasi nonstruktural maka penting untuk menetapkan fokus kajian yang akan diteliti. Untuk itu, penelitian ini akan difokuskan pada mitigasi nonstruktural melalui penataan ruang.

Penelitian ini bertujuan untuk mengetahui bagaimana mitigasi nonstruktural bencana banjir luapan Danau Tempe melalui penataan ruang dan untuk mengungkapkan kerjasama antar pemerintah kabupaten dalam mitigasi nonstruktural bencana banjir luapan Danau Tempe melalui penataan ruang. 


\section{KERANGKA TEORI}

Menurut Nurjannah $(2012: 14)$ bencana terjadi karena adanya pertemuan antara bahaya, dan kerentanan, serta adanya pemicu bencana. Hubungan antara bahaya, kerentanan dan pemicunya dapat dilihat pada Gambar 1. berikut:

GAMBAR 1. PROSES TERJADINYA BENCANA

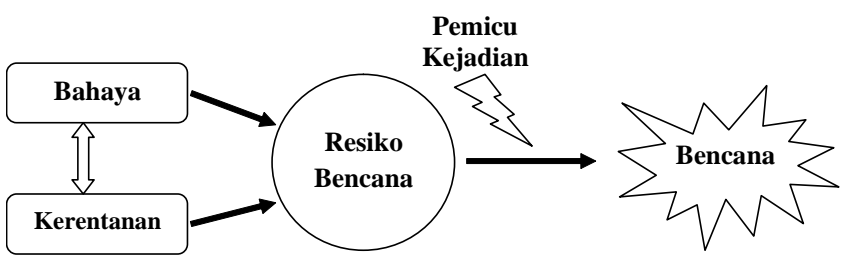

Sumber: Nurjannah dkk., 2012:14; Triutomo dkk., 2007: 8

Gambar tersebut menunjukkan unsur terjadinya bencana yaitu bahaya dan kerentanan menjadi resiko bencana. Resiko bencana berubah menjadi bencana ketika ada pemicu bencana. Jadi, suatu tempat memiliki faktor bencana tetapi tidak terdapat kerentanan maka tidak terdapat resiko bencana. Begitu sebaliknya di daerah yang memiliki kerentanan masyarakatnya tinggi tetapi tidak terdapat faktor bahaya dapat dikatakan tidak memiliki resiko bencana. Kondisi dimana terdapat bahaya dan kerentanan, tidak serta merta dapat terjadi bencana jika tidak ada pemicu bencana.

Bahaya adalah suatu fenomena alam atau buatan yang mempunyai potensi mengancam kehidupan manusia, kerugian harta benda dan kerusakan lingkungan (Nurjannah dkk., 2012:15; Triutomo dkk., 2007: 8). United Nations - International Strategy for Disaster Reduction atau UN-ISDR (dalam Triutomo dkk., 2007: 8) mengungkapkan ada lima kelompok bahaya dari berbagai aspek yaitu: dari aspek geologi, hydrometeorology, biologi, teknologi dan lingkungan. Dalam hal ini, banjir termasuk dalam kelompok bahaya dari aspek hydrometeorology.

Kerentanan merupakan suatu kondisi masyarakat yang mengarah 
ketidakmampuan dalam menghadapi ancaman bencana. Kategori kerentanan yang lebih kompleks dijelaskan oleh ADVC (2006) dalam Nurjannah dkk. (2012:22). Ada lima kategori kerentanan yaitu: kerentanan fisik, kerentanan sosial, kerentanan ekonomi, kerentanan lingkungan, dan kerentanan kelembagaan. Pertama, kerentanan fisik meliputi umur dan konstruksi bangunan, materi penyusun bangunan, infrastruktur jalan dan fasilitas umum. Kedua, kerentanan sosial meliputi persepsi tentang resiko dan pandangan hidup masyarakat yang berkaitan dengan budaya, agama, etnik, interaksi sosial, umur, jenis kelamin, dan kemiskinan. Ketiga, kerentanan ekonomi meliputi pendapatan, investasi, potensi kerugian barang/persediaan yang timbul. Keempat, kerentanan lingkungan meliputi air, udara, tanah, flora, dan fauna. Kelima, kerentanan kelembagaan meliputi tidak adanya sistem penanggulangan bencana, pemerintahan yang buruk, dan tidak sinkronya aturan yang ada.

\section{MITIGASI NON STRUKTURAL BENCANA BANJIR}

Salah satu pakar yang menjelaskan metode nonstruktural penanggulangan banjir yaitu Kodoatie dan Sugianto. Adapun metode nonstruktur pengendalian banjir menurut Kodoatie dan Sugiyono (2002) yaitu:

a. Manajemen dataran banjir yaitu mencakup masalah penataan ruang, pemberlakuan aturan khusus dan pengoptimalan dataran banjir.

b. Pengaturan tata guna lahan di daerah aliran sungai yang meliputi penataan kawasan, proporsi luas dan tata cara penggunaan kawasan. Selain itu, untuk mencegah laju erosi, pengelolaan lahan yang dapat dilakukan meliputi sistem pengelolaan, pola tanam, jenis tanaman, kemampuan tanah, elevasi dan kelerengan tanah.

c. Pengelolaan daerah pengaliran sungai (DPS) dimaksudkan untuk menghemat dan menyimpan air serta konservasi tanah. Pengelolaan DPS ini meliputi pemeliharaan vegetasi di bagian 
hulu, penanaman dan pemeliharaan vegetasi untuk mengendalikan kecepatan air dan erosi tanah sepanjang DPS, pengaturan dan bangunan pengendali banjir di daerah yang muda tererosi.

d. Penyuluhan pada masyarakat terhadap permasalahan banjir yang bertujuan untuk meningkatkan kesadaran masyarakat untuk peduli akan pencegahan terhadap bahaya banjir.

e. Pemanfaatan daerah bantaran sungai dengan aktifitas yang bersifat sementara sehingga fungsi bantaran sungai tidak terganggu dan tidak menimbulkan permasalahan dan kerugian ketika banjir datang.

Menurut Sukandarrumidi (2010:146-147), upaya mitigasi bencana banjir tanpa membedakan antara mitigasi struktural dan non yaitu:

a. Melakukan reboisasi secara menyeluruh di wilayah DAS,

b. Memberlakukan aturan larangan membangun di areal sempadan sungai dengan jarak 100 meter dari tepi sungai kecuali bangunan sarana dan prasarana sungai,

c. Memberlakukan larangan memanfaatkan sungai sebagai tempat pembuangan sampah,

d. Melakukan normalisasi sungai secara selektif,

e. Membentuk dinas yang mempunyai otoritas sebagai pengelola sungai untuk mengawasi dan menjaga pengelolaan wilayah sempadan sungai,

Beberapa tindakan mitigasi nonstruktural dijelaskan lebih detail oleh Sastrodihardjo (2010: 60-65) yaitu:

a. Konservasi tanah dan air di daerah aliran sungai (DAS) hulu untuk mengendalilan debit air, erosi dan sedimentasi di dasar sungai. Konservasi ini dengan melakukan pembangun terasering, penghijauan, reboisasi, sumur resapan dll.

b. Pengelolaan dataran banjir melalui penataan ruang dan rekayasa di daerah banjir. Rekayasa yang dimaksud yaitu rekayasa bangunan, rekayasa pertanian seperti pemilihan jenis tanaman dan 
perangkat lunak seperti flood plain zoning, flood risk map, serta pemasangan rambu-rambu peringatan

c. Penataan ruang dan rekayasa di daerah DAS hulu.

d. Penyuluhan dan penegakan hukum misalnya dalam bidang tata ruang, pembudidayaan dataran banjir, tidak mendirikan bangunan di daerah banjir dll.

e. Pengelolaan sampah, penetapan sempadan sungai yang diikuti dengan penetapan hukum

f. Penyuluhan dan pendidikan masyarakat melalui berbagai media untuk meningkatkan pemahaman, kepedulian dan peran serta masyarakat dalam mengatasi masalah banjir

g. Pengurangan kemiskinan.

\section{PENATAAN RUANG}

Penataan ruang di Indonesia diatur dalam UU No 26 Tahun 2007 tentang Penataan Ruang. Dalam Pasal 1 tentang ketentuan umum, penataan ruang didefinisikan sebagai suatu sistem proses perencanaan tata ruang, pemanfaatan ruang dan pengendalian pemanfaatan ruang. Terdapat tiga unsur penting penataan ruang yang diatur dalam pasal tersebut yaitu perencanaan tata ruang, pemanfaatan ruang dan pengendalian pemanfaatan ruang.

Perencanaan tata ruang merupakan proses menentukan struktur ruang dan pola ruang meliputi penyusunan dan penetapan rencana tata ruang. Pemanfaatan ruang adalah upaya mewujudkan struktur ruang dan pola ruang sesuai dengan rencana tata ruang melalui penyusunan dan pelaksanaan program beserta pembiayaannya. Adapun yang ketiga adalah pengendalian pemanfaatan ruang sebagai upaya untuk mewujudkan tertib tata ruang. Ketiga unsur penting penataan ruang yang diawali oleh perencanaan, diwujudkan dengan pemanfaatan dan dikontrol dengan pengendalian pemanfaatan ruang.

Lebih lanjut, terdapat hal penting yang diatur dalam penataan 
ruang yaitu struktur ruang dan pola ruang. Struktur ruang adalah susunan pusat-pusat permukiman dan sistem jaringan prasarana dan sarana yang berfungsi sebagai pendukung kegiatan masyarakat yang secara hierarki memiliki hubungan fungsional. Sedangkan pola ruang didefinisikan sebagai distribusi peruntukan ruang dalam suatu wilayah yang meliputi peruntukan ruang untuk fungsi lindung dan fungsi budidaya. Wilayah fungsi lindung adalah wilayah yang berfungsi untuk melindungi kelestarian lingkungan hidup yang mencakup SDA dan sumber daya buatan. Sementara wilayah fungsi budidaya yaitu wilayah yang ditetapkan untuk dibudidayakan atas dasar kondisi dan potensi SDA, SDM, dan sumber daya buatan.

Kawasan lindung dalam pola ruang yaitu: kawasan yang memberikan perlindungan kawasan bawahannya; kawasan suaka alam dan cagar budaya; kawasan rawan bencana alam; dan kawasan lindung lainnya seperti taman buru, cagar biosfer, kawasan perlindungan plasma nutfah, kawasan pengungsian satwa, dan terumbu karang. Adapun yang termasuk kawasan budidaya yaitu kawasan peruntukan hutan produksi, kawasan peruntukan hutan rakyat, kawasan peruntukan pertanian, kawasan peruntukan perikanan, kawasan peruntukan pertambangan, kawasan peruntukan permukiman, kawasan peruntukan industri, kawasan peruntukan pariwisata, kawasan tempat beribadah, kawasan pendidikan, dan kawasan pertahanan keamanan.

\section{PEMANFAATAN RUANG DAERAH ALIRAN SUNGAI}

Daerah aliran sungai (DAS) dapat dipahami sebagai semua daerah yang dilalui oleh air hujan mulai dari punggung bukit sampai di muara sungai. Dari hulu sampai hilir, air hujan dapat mengalir melalui hutan, sawah, ladang, perumahan, rawa, sungai dan bermuara di danau atau di laut (Ditjen Tata Ruang dan Pengembangan Wilayah dalam Kodoatie dan Syarif, 2010). Masing-masing lahan yang dilalui oleh air hujan menuju ke muara sungai memiliki 
pengaruh yang berbeda-beda terhadap kecepatan debit air menuju ke sungai.

Diantara semua lahan yang dilalui air, hutan merupakan lahan yang paling berperan untuk menahan laju debit air menuju ke sungai. Jika hutan dijadikan referensi maka perubahan debit air akibat perubahan tata guna lahan hutan menjadi padang rerumputan akan meningkatkan debit air sebesar 2,3-2,5 kali; untuk taman meningkat 1,7-5,0 kali, untuk sawah meningkat 2,5-9 kali, menjadi perumahan meningkat 5-20 kali, industri dan perdagangan menjadi 6-25 kali, jalan beton/aspal menjadi 6,3-35 kali. Peningkatan debit air sungai inilah yang menyebabkan terjadinya banjir (Kodoatie \& Sjarif, 2010).

Faktor pemanfaatan lahan beperanan penting dalam pengurangan atau peningkatan debit air yang juga berarti berpengaruh terhadap terjadinya banjir. Penutupan lahan yang didominasi pemukiman secara otomatis lebih berpotensi menyebabkan banjir jika dibandingkan dengan hutan. Pemanfaatan lahan di DAS penting perlu direncanakan dan dikendalikan dengan baik. Pada dasarnya, pengaturan DAS memperbaiki kondisi hidrologis DAS, sehingga tidak menimbulkan banjir pada musim hujan dan kekeringan pada musim kemarau dan menekan laju erosi DAS serta menekan laju sedimentasi pada alur sungai di bagian hilir (Kodoatie \& Sugiyanto, 2007:231-232). Pemerintah melalui UU No 26 Tahun 2007 di jabarkan dalam PP No 26 Tahun 2008 tentang Rencana Tata Ruang Wilayah Nasional, menetapkan kebijakan pengembangan kawasan lindung. Kebijakan pemeliharaan dan perwujudan kelestarian fungsi lingkungan hidup diantaranya dengan mewujudkan kawasan berfungsi lindung dalam satu wilayah provinsi sebesar 30\% dari luas pulau sesuai dengan kondisi ekosistemnya. Salah satu kawasan berfungsi lindung yaitu kawasan yang memberikan perlindungan terhadap kawasan bawahannya. Kawasan ini terdiri dari kawasan hutan lindung, kawasan bergambut dan kawasan resapan air. 
Penetapan kawasan lindung juga sekaligus menjadi pembatasan kawasan budidaya pada kawasan tersebut sehingga potensi pembukaan lahan akibat kegiatan budidaya dapat dikurangi.

\section{KERJASAMA ANTAR PEMERINTAH DAERAH}

Kerjasama antar pemerintah daerah diatur dalam PP No 50 Tahun 2007 tentang Tata Cara Kerjasama Antar Daerah yang kemudian dijabarkan secara teknis dalam PerMendagri No 22 Tahun 2009 tentang Petunjuk Teknis Tata Cara Kerja Sama Antar Daerah. Pihak yang menjadi subjek kerja sama dalam kerjasama daerah yaitu gubernur, walikota, bupati dan pihak ketiga. Adapun objek kerja samanya adalah seluruh urusan pemerintahan yang telah menjadi kewenangan daerah otonom dan dapat pula berupa penyediaan pelayanan publik. Sedangkan hasil dari kerjasama dapat berupa uang, surat berharga, aset, atau nonmaterial berupa keuntungan. Bentuk/ model kerjasama antar daerah yang dapat dilakukan menurut Permendagri Nomor 22 Tahun 2009 yaitu:

a. Pelayanan bersama dan/ atau antar daerah

b. Pengembangan sumber daya manusia

c. Pelayanan dengan pembayaran retribusi

d. Perencanaan dan pengurusan layanan publik tertentu yang dilaksanakan secara terpisah oleh masing-masing pemerintah daerah

e. Pembelian penyediaan pelayanan dari daerah lain dengan bayaran tertentu dan pertukaran layanan

f. Pemanfaatan peralatan yang bisa digunakan bersama

g. Penyelarasan kebijakan dan pengaturan tertentu

Dalam hal penataan ruang, kerja sama antar pemerintah daerah dapat dilakukan dalam bentuk insentif dan disinsentif. Insentif dari pemerintah daerah kepada pemerintah daerah lainnya dapat berupa pemberian kompensasi dari pemerintah daerah penerima manfaat kepada daerah pemberi manfaat atas manfaat yang diterima oleh 
daerah penerima manfaat; kompensasi pemberian penyediaan sarana dan prasarana; kemudahan perizinan bagi kegiatan pemanfaatan ruang yang diberikan oleh pemerintah daerah penerima manfaat kepada investor yang berasal dari daerah pemberi manfaat; dan/ atau publikasi atau promosi daerah. Sebaliknya disinsentif dari pemerintah daerah kepada pemerintah daerah lainnya dapat berupa: pengajuan pemberian kompensasi dari pemerintah daerah pemberi manfaat kepada daerah penerima manfaat; pembatasan penyediaan sarana dan prasarana; dan/atau persyaratan khusus dalam perizinan bagi kegiatan pemanfaatan ruang yang diberikan oleh pemerintah daerah pemberi manfaat kepada investor yang berasal dari daerah penerima manfaat. Mekanisme pemberian insentif atau disinsentif antar pemerintah daerah ditetapkan berdasarkan kesepakatan bersama antar pemerintah daerah yang bersangkutan.

\section{METODE PENELITIAN}

Jenis penelitian yang digunakan dalam penelitian ini adalah penelitian deskriptif kualitatif. Penelitian deskriptif kualitatif adalah penelitian yang berusaha mendeskripsikan suatu gejala, peristiwa, atau kejadian yang terjadi saat sekarang (Noor 2012:34). Penelitian ini akan mendeskripsikan mitigasi nonstruktural bencana banjir luapan Danau Tempe melalui penataan ruang. Penelitian ini akan dilaksanakan di Pemerintah Provinsi Sulawesi Selatan yaitu di beberapa SKPD yang terkait dengan penataan ruang dan penanggulangan bencana banjir Danau Tempe serta di tiga Kabupaten yang berada di pesisir Danau Tempe. Tiga kabupaten yang dimaksud yaitu Kabupaten Wajo, Kabupaten Sidenreng Rappang dan Kabupaten Soppeng. Teknik pengumpulan data yang digunakan adalah teknik triangulasi yaitu teknik gabungan dari berbagai teknik pengumpulan data yang ada. Teknik triangulasi menggabungkan teknik wawancara, observasi dan dokumentasi (Rostin dan Kimbal, 2012:53).

Teknik pemilihan informan pada penelitian ini adalah teknik 
snowball sampling,dimulai dengan memilih informan tertentu dengan pertimbangan memberikan data yang diperlukan dan selanjutnya berdasarkan data tersebut, dapat dipertimbangkan untuk untuk memilih informan lainnya untuk mendapat data yang lebih lengkap (Sugiyono 2012:219). Adapun informan dalam penelitian ini yaitu: Pemerintah Provinsi Sulawesi Selatan, Pemerintah Kabupaten Sidenreng-Rappang, Soppeng dan Wajo serta masyarakat di masingmasing kabupaten.

Teknik yang digunakan dalam menganalisis data dalam penelitian ini didasarkan pada jenis data yang didapatkan. Untuk data sekunder berupa angka disajikan dalam bentuk tabel, dan diagram kemudian dianalisis menggunakan metode statistik deskriptif. Tahap analisis selanjutnya didasarkan pada data primer yang berupa data kata-kata dianalisis dengan teknik analisis deskriptif kualitatif.

\section{PEMBAHASAN}

\section{MITIGASI NONSTRUKTURAL MELALUI PENATAAN RUANG}

Secara umum, bencana terjadi akibat adanya ancaman bahaya bertemu dengan kerentanan masyarakat serta adanya pemicu bencana (Nurjannah dkk. 2012:14). Dalam konteks bencana banjir, ancaman bahayanya yaitu banjir itu sendiri. Sementara itu kerentanan masyarakat dapat berupa kerentanan fisik, sosial, kelembagaan, ekonomi dan lingkungan. Adapun pemicu bencana banjir yaitu curah hujan yang tinggi. Kerangka inilah yang akan digunakan untuk menganalisis bencana banjir luapan Danau Tempe.

Penyebab utama banjir luapan Danau Tempe adalah karena sedimentasi danau yang terus berlanjut. Sedimentasi itu sendiri disebabkan karena erosi, sampah yang menumpuk di danau dan eceng gondok. Erosi disebabkan karena pertanian lahan kering khususnya di daerah pegunungan dan alih fungsi lahan yang dulunya hutan menjadi perumahan ataupun pemukiman. Sampah juga menjadi penyebab terjadinya pendangkalan. Masayarakat sekitar 
belum sadar dalam pengelolaan sampah yang benar baik samapah rumah tangga maupun sampah hasil pertanian (pascapanen) yang ikut terbawa arus menuju Danau Tempe. Efeksamping dari pembududayaan enceng gondok yang dilakukan oleh nelayan sebagai penangkaran ikan adalah munculnya sedimentasi dasar danau. Pada musim kemarau, eceng gondok yang mati mengering tersebar diseluruh badan danau dan menyebabkan pendangkalan. Ketika musim hujan tiba, danau yang terlanjur Dangkal akhirnya tidak mampu menampung air dan meluap ke sekitar danau. Pada saat inilah banjir terjadi.

Banjir tidak akan menjadi bencana jika tidak ada kerentanan masyarakat di daerah banjir. Kenyataannya di pesisir Danau Tempe terdapat kerentanan masyarakat. Kerentanan sosial masyarakat di pesisir Danau Tempe terlihat dari adanya pemukiman dengan tingkat kepadatan rendah hingga tinggi. Di pesisir danau tempe terdapat perumahan pedesaan yang tingkat kepadatan rendah dan perkotaan dengan tingkat kepadatan sedang hingga tinggi. Wilayah di sekitar Danau Tempe juga dimanfaatkan sebagai lahan pertanian sehingga bahwa ketika terjadi banjir, banyak sawah yang tergenang air hingga terjadi gagal panen. Hal ini tentu saja merugikan masyarakat yang bekerja sebagai petani sehingga dapat dikategorikan kerentanan ekonomi. Eceng gondok di permukaan danau menjadi kerentanan lingkungan karena jika eceng gondok yang terbawa angin atau arus air menabrak rumah warga, dapat merusak rumah warga pada umumnya adalah rumah kayu yang tentu lebih rentan rusak terkena eceng gondok. Hal tersebut merupakan kerentanan fisik yang diperparah oleh kerentanan lingkungan. Kerentanan terakhir yaitu kerentanan kelembagaan. Hasil penelitian menunjukkan kecenderungan adanya dukungan dari pemerintah untuk kegiatan pertanian di endapan danau pada saat musim kering. Hal tersebut pada bagian sebelumnya diidentifikasi sebagai penyebab banjir Danau Tempe, terdapat pula kecenderungan kurangnya upaya 
mitigasi bencana oleh pemda karena lebih fokus pada tanggap darurat bencana. Penyebab bencana banjir dapat dilihat pada Gambar 2.

GAMBAR 2. SKEMA PENYEBAB BANJIR DANAU TEMPE

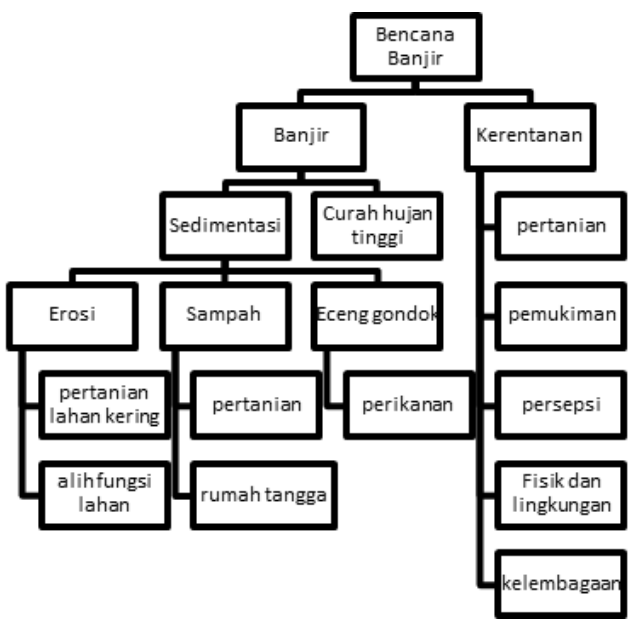

Diantara kerentanan masyarakat pesisir Danau Tempe, terdapat kerentanan yang berada pada zona abu-abu. Di satu sisi dapat dianggap kerentanan dan di sisi lain dapat juga menjadi ketangguhan. Salah satunya adalah persepsi masyarakat tentang bencana yang menganggap banjir adalah berkah. Danau Tempe yang mengering menjadi lahan pertanian yang cukup luas dan subur, sebaliknya Danau Tempe yang meluap menjadi lokasi penangkapan ikan yang melimpah. Hal tersebut menyebabkan masyarakat menyesuaikan gaya hidupnya dengan kondisi alam dengan berprofesi ganda. Pada musim hujan, masyarakat bekerja sebagai nelayan. Sebaliknya pada musim kering, masyarakat bekerja sebagai petani palawija dengan memanfaatkan badan danau yang telah mengiring. Dengan demikian, masyarakat tidak terbebani dengan kejadian banjir. Hal tersebut membentuk persepsi bahwa banjir itu berkah dan oleh karena itu dapat dianggap sebagai ketangguhan menghadapi bencana. 


\section{Dari sisi sebaliknya, persepsi demikian menimbulkan kesan} bahwa masyarakat telah nyaman dengan kondisi banjir sehingga penanggulangan bencana banjir tidak diprioritaskan. Wacana pengerukan Danau Tempe sebagai salah satu upaya penanggulangan bencana banjir bahkan ditolak oleh sebagian masyarakat karena akan menghilangkan lahan pertanian pada saat musim kering. Disamping itu, kerugian akibat banjir Danau Tempe juga tidak dapat dikatakan sedikit. Masyarakat di pesisir Danau Tempe yang bekerja sebagai petani dan nelayan kemungkinan tidak merasakan dampak yang luar biasa merugikan dari bencana banjir luapan Danau Tempe. Tetapi jika melihat catatan dampak bencana, selain rumah yang terendam, banyak sawah yang gagal panen, fasilitas umum yang rusak serta pengeluaran anggaran negara untuk memberikan bantuan kepada korban bencana. Pemerintah dan masyarakat yang mengatakan bahwa banjir itu berkah mungkin tidak memperhatikan dampak yang seperti itu. Pada posisi ini, persepsi yang menganggap bencana adalah berkah dapat dinilai sebagai kerentanan terhadap bencana.

Kerentanan lain yang juga dapat dikatakan berada pada zona abu-abu adalah kondisi rumah warga di pesisir Danau Tempe. Pada umumnya, rumah masyarakat di pesisir Danau Tempe adalah rumah panggung berbahan kayu. Dalam hal ini, Sukandarrumidi (2010) mengungkapkan salah satu upaya mitigasi bencana banjir adalah dengan membuat rumah panggung dan menyiapkan loteng untuk penyelamatan diri. Jika berdasar pada pendapat tersebut, maka seharusnya rumah masyarakat di pesisir Danau Tempe telah aman dari ancaman bencana banjir. Namun fakta di lapangan menunjukkan bahwa faktor ketinggian bangunan rumah panggung bukan jaminan rumah masyarakat aman dari bencana banjir. Faktor bahan bangunan juga penting untuk diperhatikan. Rumah panggung dapat menyelamatkan barang-barang dari ancaman kerusakan akibat terendam banjir karena tempatnya yang lebih tinggi dari elevasi banjir. Tetapi dalam kasus bencana banjir Luapan Danau Tempe, 
ketinggian bangunan rumah panggung saja tidak cukup untuk membuat masyarakat aman dari ancaman banjir. Faktor bahan bangunan juga penting untuk diperhatikan. Rumah berbahan kayu lebih rentan rusak terbawa arus atau tertabrak oleh benda-benda yang terbawa arus. Dalam kasus bencana banjir luapan Danau Tempe, eceng gondok merupakan ancaman yang serius terhadap rumah panggung berbahan kayu. Hal ini yang menyebabkan rumah panggung berbahan kayu di sekitar Danau Tempe juga rentan terhadap bencana banjir.

Kajian tentang penyebab bencana banjir luapan Danau Tempe serta ketangguhan dan kerawanan masyarakat tersebut di atas dijadikan dasar dalam meneropong penataan ruang berdasarkan peraturan daerah rencana tata ruang wilayah terbaru di Kabupaten Sidenreng Rappang, Soppeng dan Wajo. Ada sebelas bagian yang menjadi perhatian dari rencana tata ruang wilayah masing-masing kabupaten diantaranya: jaringan persampahan, jalur dan ruang evakuasi bencana, kawasan hutan lindung, kawasan resapan air, kawasan perlindungan setempat, kawasan rawan bencana, kawasan hutan produksi, kawasan hutan rakyat, kawasan peruntukan pertanian, kawasan peruntukan perikanan dan kawasan peruntukan pemukiman. Sebelas bagian tersebut dalam peraturan daerah rencana tata ruang wilayah masing-masing kabupaten termasuk ke dalam dua kategori besar yaitu: pola ruang yang mencakup kawasan hutan lindung, kawasan resapan air, kawasan perlindungan setempat, kawasan rawan bencana, kawasan hutan produksi, kawasan hutan rakyat, kawasan peruntukan pertanian, kawasan peruntukan perikanan dan kawasan peruntukan pemukiman; dan struktur ruang yang mencakup sistem jaringan persampahan serta jalur dan ruang evakuasi bencana. Kedua kategori tersebut kemudian dikaji dari sudut pandang mitigasi nonstruktural bencana banjir. 


\section{A. KAWASAN LINDUNG}

Kawasan lindung yang dibahas dalam penelitian ini terdiri atas kawasan yang memberikan perlindungan terhadap kawasan bawahannya yang meliputi: hutan lindung dan kawasan resapan air; kawasan perlindungan setempat yang meliputi: sempadan sungai dan daerah sekitar danau/waduk; serta kawasan rawan bencana banjir. Dalam peraturan daerah RTRW masing-masing kabupaten, kawasan yang memberikan perlindungan terhadap kawasan bawahannya ditetapkan dengan tujuan untuk mencegah erosi dan sedimentasi, menjaga fungsi hidrologis tanah untuk menjamin ketersediaan unsur hara tanah, air tanah, dan air permukaan serta memberikan ruang yang cukup bagi peresapan air hujan untuk keperluan penyediaan kebutuhan air tanah dan pengontrol tata air permukaan. Dari tujuan penetapan kawasan ini saja sudah tampak jelas upaya mitigasi bencana khususnya yang berkaitan dengan bencana banjir.

Dari perspektif strategi mitigasi bencana menurut Schwab dkk. (2007), penetapan kawasan yang memberikan perlindungan terhadap kawasan bawahannya dapat dimasukkan dalam strategi perlindungan sumber daya alam. Tujuan dari strategi perlindungan sumber daya alam ini adalah untuk mengurangi dampak bencana alam dengan menjaga dan memulihkan lingkungan beserta fungsi mitigasinya melalui misalnya kontrol erosi dan sedimentasi serta pelestarian lingkungan. Menurut Sastrodihardjo (2010) adalah konservasi di daerah hulu untuk menekan aliran permukaan serta memperkecil debit puncak banjir serta pengendalian erosi untuk mengurangi pendangkalan sungai. Sebagaimana telah diidentifikasi sebelumnya bahwa penyebab banjir luapan Danau Tempe yaitu erosi dan sedimentasi sehingga penetapan kawasan hutan lindung dan resapan air memegang peranan penting dalam pencegahan keberlanjutan erosi dan sedimentasi yang akan menambah dampak bencana banjir. 
Penetapan kawasan perlindungan terhadap kawasan bawahannya dapat dikatakan sebagai langkah awal dalam melakukan konservasi di daerah hulu sungai. Langkah selanjutnya yang tidak kalah pentingnya adalah pemberlakuan peraturan zonasi di masing-masing kawasan untuk mempertahankan fungsi kawasan sebagai wilayah perlindungan. Penetapan kawasan hutan lindung dan kawasan resapan air tidak akan memberikan dampak yang signifikan dalam mitigasi bencana banjir tanpa disertai dengan penegakan aturan zonasi di masing-masing kawasan.

Baik Kabupaten Sidenreng Rappang, Soppeng dan Wajo telah menetapkan kawasan hutan lindung dan kawasan resapan air di masing-masing wilayahnya. Khususuntuk kawasan hutan lindung, penetapannya didasarkan pada RTRW Provinsi. Sementara itu, penetapan hutan lindung di RTRW Provinsi didasarkan pada SK Menhut nomor SK.434/Menhut-II/2009 tentang kawasan hutan di Sulawesi Selatan. Dalam SK Menhut tersebut terlihat adanya perubahan luasan kawasan hutan yang ditetapkan pada surat keputusan sebelumnya. Pada tahun 1999 kawasan hutan di Sulawesi Selatan ditetapkan dengan luas 3.879.771 hektar. Sementara itu, berdasarkan SK Menhut yang baru kawasan hutan ditetapkan dengan luas 2.725.796 hektar. Hal ini berarti luas kawasan hutan di Sulawesi Selatan berkurang 1.153.975 hektar dalam sepuluh tahun.

Indikasi pengurangan luas kawasan hutan dalam revisi RTRW ke depan juga sudah mulai tampak dengan adanya konflik lahan warga yang masuk kawasan hutan. Pemerintah Kabupaten Soppeng telah mengirimkan surat permohonan untuk merevisi luas kawasan hutan yang telah di tetapkan oleh pemerintah provinsi Sulawesi Selatan. Pemerintah Kabupaten Soppeng meminta kepada pemerintah provinsi wilayah yang telah diklaim sebagai milik warga tidak ditetapkan sebagai kawasan hutan. Jika permohonan tersebut dikabulkan maka luas kawasan hutan di Sulawesi Selatan kembali 
akan berkurang. Berkurangnya luas kawasan hutan dari tahun 1999 sampai tahun 2009 serta kasus sengketa lahan masyarakat dalam kawasan hutan di Kabupaten Soppeng mengindikasikan tidak konsistennya penetapan kawasan hutan dengan penegakan aturan dalam kawasan tersebut.

Selain kawasan yang memberikan perlindungan terhadap kawasan bawahannya, kawasan lindung lainnya yang dikaji dalam mitigasi nonstruktural bencana banjir luapan Danau Tempe adalah kawasan perlindungan setempat. Kawasan ini terdiri dari kawasan sempadan sungai dan kawasan sekitar danau/waduk. Sukandarrumidi (2010) mengungkapkan salah satu metode nonstruktur pengendalian banjir yaitu memberlakukan aturan larangan membangun di areal sempadan sungai dengan jarak 100 meter dari tepi sungai kecuali bangunan sarana dan prasarana sungai. Dalam ketentuan sempadan sungai di Kabupaten Sidenreng Rappang, Soppeng dan Wajo, pendapat dari Sukandarrumidi tersebut diberlakukan penetapan sempadan sungai yang tidak bertanggul di luar kawasan pemukiman. Sementara itu untuk sempadan sungai yang bertanggul ditetapkan dengan jarak 5 meter dari tanggul luar dan untuk sempadan sungai tidak bertanggul di kawasan pemukiman ditetapkan dengan lebar 50 meter dari sungai.

Dalam peraturan zonasi untuk kawasan sempadan sungai, tidak secara eksplisit disebutkan larangan mendirikan bangunan tetapi ditetapkan aturan bangunan yang dibolehkan hanya untuk ruang terbuka hijau, sarana dan prasarana sungai, dan bangunan pemantau banjir, kegiatan transportasi sungai, rekreasi air dan budidaya pertanian dengan tanaman yang tidak mengurangi kekuatan struktur tanah. Adapun kegiatan yang dilarang yaitu kegiatan yang dapat mengganggu fungsi perlindungan kawasan sungai misalnya kegiatan membuang sampah di sungai, serta kegiatan yang menghalangi jalur evakuasi bencana.

Budidaya tanaman di daerah sempadan sungai sungai dapat 
dianggap sebagai upaya mitigasi bencana. Kodoatie dan Sugiyono (2002) menyebutkan salah satu mitigasi nonstruktur bencana banjir adalah dengan pengelolaan daerah pengaliran sungai (DPS) melalui penanaman dan pemeliharaan vegetasi untuk mengendalikan kecepatan air dan erosi tanah di sepanjang DPS. Tanaman di daerah sempadan sungai akan menghambat laju air menuju ke daerah hilir sekaligus juga mencegah erosi dari daerah sempadan sungai. Selain budidaya tanaman di daerah sempadan sungai, aturan zonasi sempadan sungai juga melarang kegiatan membuang sampah di sungai. Dalam kasus banjir luapan Danau Tempe, sampah dianggap menjadi salah satu penyebab banjir. Penetapan pembatasan bangunan, pemberian izin penanaman vegetasi dan larangan membuang sampah pada aturan sempadan sungai di Kabupaten Sidenreng Rappang, Soppeng dan Wajo mengindikasikan bahwa aturan zonasi tersebut telah memperhatikan aspek mitigasi bencana.

Belum ada ahli yang membahas masalah mitigasi banjir yang dikaitkan dengan kawasan sekitar danau meskipun merupakan kawasan lindung. Jika logika perlindungan sempadan sungai digunakan dalam menganalisis kawasan sekitar danau maka disimpulkan bahwa kawasan sekitar danau idealnya diberlakukan pembatasan bangunan dan larangan membuang sampah. Dalam aturan zonasi kawasan sekitar danau, pembatasan pendirian bangunan telah ditetapkan kecuali untuk bangunan rekreasi dan pemantauan ketinggian air. Sayangnya, larangan membuang sampah tidak ditemukan dalam aturan zonasi kawasan sekitar danau. Sementara itu, masalah sampah di Danau Tempe merupakan masalah serius karena dapat menyebabkan pendangkalan danau.

Dalam kasus di sekitar Danau Tempe,di Kabupaten Sidenreng Rappang, Pemerintah Kabupaten tidak menetapkan kawasan sekitar Danau Tempe sebagai kawasan perlindungan setempat. Dengan demikian, ketentuan kawasan perlindungan sekitar danau atau waduk beserta dengan aturan zonasinya tidak berlaku di desa-desa 
atau kelurahan di pesisir Danau Tempe di wilayah Kabupaten Sidenreng Rappang. Sementara itu ada dua Kelurahan dan satu Desa yang tampak di peta berada langsung di pesisir Danau Tempe. Ketiadaan aturan zonasi kawasan sekitar Danau Tempe dapat berakibat perkembangan pembangunan sulit dikendalikan. Kemungkinan terburuk adalah dampak bencana akan bertambah seiring dengan berkembangnya pembangunan di dataran banjir. Semakin banyak bangunan di sekitar Danau maka semakin banyak pula bangunan yang tenggelam pada saat terjadi banjir.

Pelaksanaan penataan kawasan perlindungan setempat dapat dikatakan belum berjalan. Pembahasan pada bagian pelaksanaan penataan ruang menunjukkan bahwa di daerah-daerah yang ditetapkan sebagai kawasan perlindungan setempat belum dilaksanakan penataan kawasan. Demikian pula peraturan zonasi untuk kawasan tersebut juga masih belum dijalankan. Faktor kesadaran masyarakat; belum adanya rencana detail tata ruang serta belum adanya aturan penertiban menjadi penyebab penataan kawasan sempadan sungai dan kawasan sekitar danau belum dilaksanakan.

Selain kawasan yang memberikan perlindungan terhadap kawasan bawahannya dan kawasan perlindungan setempat, kawasan lain yang dibahas dalam penelitian ini adalah kawasan rawan bencana khususnya rawan bencana banjir. Penataan kawasan rawan bencana dibahas oleh banyak ahli sebagai bagian dari mitigasi bencana diperlukan penataan ruang dan pemberlakuan aturan khusus. Manajemen pengelolaan dataran banjir harus melalui penataan ruang dan rekayasa di daerah banjir yang. Wujud dari manajemen dataran banjir yang ditemukan dalam RTRW kabupaten Sidenreng Rappang, Soppeng dan Wajo adalah penetapan daerah rawan bencana banjir dan peraturan zonasi daerah rawan bencana banjir. Dalam peraturan daerah RTRW di masing-masing kabupaten, semua kecamatan yang wilayahnya terdampak bencana banjir luapan Danau Tempe telah ditetapkan sebagai daerah rawan bencana banjir. Selain 
di batang tubuh perda RTRW, daerah rawan bencana banjir juga dapat terlihat pada peta rencana pola ruang RTRW Kabupaten Sidenreng Rappang dan Kabupaten Soppeng. Selain itu, pemerintah daerah telah membuat peta khusus untuk daerah rawan bencana di Kabupaten Sidenreng Rappang dan Soppeng. Khusus untuk di Kabupaten Wajo, peta daerah rawan banjir tidak ditemukan dalam peta RTRW melainkan dibuat peta resiko bencana banjir tersendiri oleh BNPB bekerja sama dengan BPBD Kabupaten Wajo. Diantara tiga kabupaten di pesisir Danau Tempe, hanya Kabupaten Wajo yang memiliki peta khusus untuk resiko bencana banjir. Di dua kabupaten lainnya hanya ada peta resiko bencana secara umum. Selain itu, di Kabupaten Sidenreng Rappang terdapat ketidaksesuaian antara batang tubuh peraturan daerah RTRW dengan peta rawan bencananya. Pada peta daerah rawan bencana, Kecamatan Panca Lautang Kabupaten Sidenreng Rappang sebagai daerah di sekitar Danau Tempe hanya terlihat sebagai daerah rawan bencana angin kencang. Sementara itu, pada batang tubuh RTRW, terdapat dua kelurahan dan satu desa yang ditetapkan sebagai daerah rawan bencana banjir.Manajemen dataran banjir dalam RTRW Kabupaten Sidenreng Rappang, Soppeng dan Wajo selain penetapan daerah rawan banjir adalah peraturan zonasi di daerah rawan banjir. Di ketiga kabupaten ditemukan peraturan zonasi daerah rawan banjir yang sama. Penekanan dari peraturan zonasi dalam RTRW di tiga kabupaten adalah pembatasan kegiatan yang menyebabkan terjadinya banjir. Aturan tersebut tampak sangat normatif sehingga dapat ditafsirkan secara bebas. Peraturan larangan kegiatan pemukiman yang secara tegas dituliskan dalam RTRW Provinsi tidak dicantumkan dalam peraturan zonasi di Kabupaten Sidenreng Rappang, Soppeng dan Wajo. Dengan peraturan yang normatif, maka pemukiman di daerah rawan banjir dapat saja dianggap dibolehkan oleh pemerintah daerah, tergantung apakah dianggap dapat menyebabkan banjir atau tidak. 
Point penting lainnya mengenai manajemen daerah banjir yaitu rekayasa bangunan daerah rawan banjir misalanya dengan model rumah panggung tidak dicantumkan dalam peraturan zonasi daerah rawan banjir. Meskipun demikian, rumah-rumah masyarakat di sekitar Danau Tempe telah menggunakan model rumah panggung. Begitu pula dengan fasilitas umum berupa kantor kelurahan dan sekolah yang ada di daerah rawan banjir telah terlihat menggunakan model rumah panggung.

\section{B. KAWASAN BUDIDAYA}

Kawasan budidaya yang dibahas dalam bagian ini adalah penataan kawasan budidaya hutan produksi, hutan produksi terbatas dan hutan rakyat yang disatukan dalam kawasan budidaya hutan; kawasan pertanian; kawasan perikanan dan kawasan perumahan. Penetapan kawasan budidaya hutan dapat dilihat sebagai upaya penanggulangan bencana banjir. Kawasan yang telah ditetapkan sebagai kawasan hutan menjadi dasar penerapan sejumlah aturan tertentu. Penetapan kawasan hutan dimaksudkan untuk menjaga keberadaannya sebagai hutan tetap. Untuk tujuan tersebut, pemerintah telah menetapkan UU No 18 Tahun 2013 tentang Pencegahan dan Pemberantasan Perusakan Hutan yang di dalamnya berisi aturan-aturan untuk mencegah perusakan hutan beserta dengan sanksinya.

Kawasan budidaya lainnya adalah kawasan budidaya pertanian, Penetapan kawasan peruntukan pertanian memiliki peran penting dalam pencegahan erosi dan sedimentasi. Salah satu penyebab erosi dan sedimentasi yaitu pertanian lahan kering di wilayah yang tanahnya mudah terjadi erosi Berdasarkan data dari BP DAS Jeneberang Walanae tahun 2011 beberapa daerah yang memiliki kelas lereng di atas 15\% di masing-masing Kabupaten yaitu: Kecamatan Dua Pitue, Pitu Riawa, Tellu Limpoe dan Panca Lautang di Kabupaten Sidenreng Rappang; Kecamatan Donri-Donri, 
Marioriawa, Marioriwo, Liliriaja, Lalabata, Lilirilau di Kabupaten Soppeng; dan Kecamatan Maniangpajo, Tempe, dan Sabbangparu di Kabupaten Wajo. Di sebagian wilayah kecamatan tersebut ditetapkan sebagai kawasan peruntukan pertanian yang memunculkan potensi terjadinya erosi dan sedimentasi. Namun demikian, belum dapat dipastikan apakah kawasan-kawasan yang ditetapkan sebagai kawasan peruntukan pertanian tersebut berada pada lokasi dengan kelas lereng di atas 15\%. Adanya potensi erosi dan sedimentasi yang disebabkan oleh penetapan kawasan peruntukan pertanian tidak diimbangi dengan aturan zonasi mengenai metode pertanian yang dapat mencegah erosi dan sedimentasi.

Selain itu, dalam peraturan zonasi tidak diatur masalah pengelolaan sampah sisa hasil pertanian menjadi salah satu penyebab dari sedimentasi Danau Tempe. Pada penetapan kawasan peruntukan pertanian di Kabupaten Sidenreng Rappang, Soppeng dan Sidrap terlihat bahwa semua wilayah di sekitar Danau Tempe diperuntukkan sebagai kawasan pertanian tanaman pangan. Untuk itu, penting untuk diperhatikan lokasi detail lahan pertanian yang berada di sekitar Danau Tempe khususnya tanah endapan Danau Tempe yang dijadikan lahan pertanian palawija pada saat musim kering. Sisa sampah pertanian ditinggalkan begitu saja di wilayah danau akan menumpuk dan menambah pendangkalan Danau Tempe.

Penetapan kawasan peruntukan pertanian di beberapa wilayah di Kabupaten Sidenreng Rappang, Soppeng dan Wajo dapat dianggap sebagai upaya pencegahan erosi dan sedimentasi jika dilihat dari perspektif pembatasan aktivitas pertanian di lahan-lahan yang mudah erosi. Namun di sisi lain, dapat pula menjadi penyebab erosi dan sedimentasi jika ternyata lokasi lokasi yang ditetapkan sebagai wilayah pertanian merupakan lokasi yang mudah erosi. Untuk itu, penilaian terhadap penetapan kawasan peruntukan pertanian pangan tergantung dari rencana detail penataan ruang untuk kawasan pertanian dan peraturan zonasi wilayahnya. 
Selain penataan kawasan hutan dan kawasan pertanian, kawasan lainnya yang dibahas dalam bagian ini adalah kawasan perikanan. Penetapan kawasan perikanan dalam RTRW Kabupaten Sidenreng Rappang, Soppeng dan Wajo menunjukkan bahwa semua kecamatan yang berada di pesisir Danau Tempe ditetapkan sebagai kawasan peruntukan perikanan tangkap. Pemanfaatan tanaman eceng gondok sebagai perangkap ikan menyebabkan perkembangan eceng gondok di Danau Tempe sulit diatas berpotensi besar menyebabkan sedimentasi.

Dalam peraturan zonasi kawasan peruntukan perikanan tidak diatur masalah metode penangkapan ikan. Larangan kegiatan yang berpotensi merusak fungsi kawasan yang ada pada peraturan zonasi kawasan peruntukan perikanan juga terkesan normatif sehingga tidak cukup tegas untuk membatasi metode penangkapan ikan dengan menggunakan eceng gondok. Selain itu, metode penangkapan ikan tersebut sudah dianggap sebagai budaya masyarakat sehingga sulit untuk dihilangkan. Untuk itu, penetapan kawasan Danau Tempe sebagai kawasan peruntukan perikanan tangkap berpotensi menjadi batu sandungan mitigasi bencana banjir luapan Danau Tempe.

Kawasan budidaya terakhir yaitu kawasan budidaya pemukiman. Penetapan kawasan pemukiman dapat dilihat dari sudut pandang mitigasi bencana banjir sebagai upaya mengurangi kepadatan penduduk yang bermukim di daerah rawan banjir. Dalam hal ini, Kabupaten Sidenreng Rappang dan Soppeng telah menetapkan kawasan di sekitar Danau Tempe sebagai kawasan peruntukan pemukiman pedesaan. Kawasan peruntukan pemukiman pedesaan itu sendiri diperbolehkan kegiatan pemukiman dengan kepadatan rendah dengan koefisien wilayah terbangun (KWT) maksimal 50\% dari luas kawasan. Hal tersebut menunjukkan adanya pembatasan kepadatan penduduk di daerah pedesaan.

Berbeda halnya di Kabupaten Wajo, diantara empat kecamatan 
di pesisir Danau Tempe, hanya Kecamatan Tempe yang diatur dalam peraturan daerah RTRW Kabupaten Wajo. Tiga kecamatan lain tidak diatur peruntukannya untuk kawasan perkotaan ataupun pedesaan. Sementara itu, Kecamatan Tempe ditetapkan sebagai kawasan peruntukan perkotaan. Penetapan tersebut bukan tanpa alasan mengingat Kecamatan Tempe merupakan ibu kota dari Kabupaten Wajo.

Kawasan pemukiman memiliki peran penting dalam mitigasi bencana khususnya pemukiman di daerah rawan bencana. Dalam pedoman pemanfaatan ruang kawasan rawan bencana banjir yang disusun oleh Departemen Pekerjaan Umum mengarahkan agar daerah dengan tingkat kerawanan bencana tinggi dan sedang tidak digunakan untuk kawasan perumahan. Daerah di sekitar Danau Tempe mempunyai tingkat kerawanan bencana sedang dan tinggi. Dengan berdasar kepada peta resiko bencana banjir di Kabupaten Wajo dan pedoman pemanfaatan kawasan rawan bencana banjir yang disusun oleh Departemen Pekerjaan Umum maka seharusnya di kawasan rawan bencana banjir luapan Danau Tempe tidak lagi diperuntukkan untuk kawasan pemukiman. Khusus untuk Kabupaten Sidenreng Rappang dan Soppeng tidak ada data tingkat kerawanan bencana banjirnya sehingga sulit untuk menentukan apakah kawasan di sekitar Danau Tempe dapat dijadikan kawasan pemukiman atau tidak.

\section{STRUKTUR RUANG}

Pengelolaan sampah dapat dilihat sebagai bagian dari mitigasi nonstruktural bencana banjir. Jika pengelolaan sampah berhasil maka masyarakat tidak lagi membuang sampah di sungai atau di danau. Pada akhirnya upaya ini akan mengurangi keberlanjutan proses pendangkalan di Danau Tempe. Dari uraian di atas terlihat bahwa ketiga kabupaten di sekeliling Danau Tempe telah merencanakan pengelolaan sampah di masing-masing wilayahnya. 
Sayangnya, di Kabupaten Wajo, tidak semua kecamatan direncanakan ada tempat penampungan sampah sementara. Diantara keempat kecamatan di wilayah Kabupaten Wajo, hanya Kecamatan Tempe dan Tanasitolo saja yang direncanakan ada tempat penampungan sampah sementara. Sementara itu, dua kecamatan lain yaitu Kecamatan Belawa dan Kecamatan Sabbangparu tidak disiapkan tempat penampungan sampah sementara. Padahal dari segi geografis, dua kecamatan ini dapat dikatakan berperan penting sebagai penyangga Danau Tempe. Sebab, dua kecamatan ini dilalui aliran sungai besar yang masuk ke Danau Tempe yaitu Sungai Walanae dan Sungai Bila. Selain itu, beberapa desa di kedua kecamatan ini berada di pesisir Danau Tempe. Tidak adanya pengelolaan persampahan di kedua kecamatan tersebut membuka peluang masyarakat untuk terus membuang sampah di Sungai dan di Danau. Jika demikian halnya, maka pendangkalan Danau Tempe yang disebabkan karena sampah masyarakat masih akan terus terjadi. Berbeda halnya dengan Kabupaten Soppeng dan Sidenreng Rappang yang mana di semua kecamatan direncanakan ada tempat penampungan sampah sementara.

Penyediaan tempat pembuangan sampah sementara tidak lantas menyelesaikan masalah persampahan. Kenyataanya masyarakat sudah terbiasa membakar sampah atau membuang sampah di sungai. Selain itu, sampah yang banyak menyebabkan masalah pendangkalan Danau Tempe adalah sampah sisa hasil pertanian. Dalam peraturan zonasi kawasan pertanian tidak diatur masalah pengelolaan sampah sisa hasil pertanian. Hal tersebut memungkinkan masyarakat untuk terus mengelola sampah dengan cara membakar atau membuang ke sungai/danau. Meskipun pada aturan zonasi kawasan sempadan sungai telah diatur larangan membuang sampah di sungai namun kenyataannya aturan tersebut belum ditegakkan. Pada akhirnya, praktek membuang sampah di sungai masih terus berlanjut.

Pearturan daerah RTRW masing-masing kabupaten telah 
mengatur masalah penyediaan jalur evakuasi bencana. Khusus untuk wilayah di sekitar Danau Tempe, Kabupaten Sidenreng Rappang telah merencanakan jalur evakuasi di Kecamatan Panca Lautang. Kabupaten Soppeng telah merencanakan jalur dan ruang evakuasi di Kecamatan Donri-Donri dan Marioriawa. Sementara itu, Kabupaten Wajo telah merencanakan jalur evakuasi bencana di Kecamatan Tempe, Tanasitolo dan Belawa. Khusus untuk Kabupaten Soppeng dan Kabupaten Sidenreng Rappang telah menyiapkan jalur evakuasi bencana di semua Kecamatan di pesisir Danau Tempe. Namun tidak demikian halnya Kabupaten Wajo yang tidak merencanakan jalur evakuasi bencana untuk Kecamatan Sabbangparu. Sementara itu, Kecamatan Sabbangparu merupakan salah satu daerah yang terdampak banjir luapan Danau Tempe karena berada persis di pesisir Danau Tempe.

Dari segi perencanaan, terlihat bahwa Kabupaten Soppeng dan Kabupaten Wajo lebih detail merencanakan jalur dan ruang evakuasi bencana. Selain merencanakan jalur evakuasi, Kabupaten Soppeng dan Kabupaten Wajo juga menetapkan rencana ruang evakuasi sebagai tempat berkumpul sementara ketika terjadi bencana. Namun demikian, rencana ruang evakuasi bencana di Kabupaten Wajo tampak tidak sinkron dengan rencana jalur evakuasinya. Terlihat banyak ruang evakuasi bencana yang tidak disertai dengan jalur evakuasi bencana. Berbeda dengan dua kabupaten lainnya, rencana ruang evakuasi bencana tidak ditemukan di rencana tata ruang Kabupaten Sidenreng Rappang. Ruang evakuasi, selain menjadi tempat berkumpul saat bencana, juga menjadi ujung dari jalur evakuasi.

Dari sudut pandang perencanaan dan peraturan zonasi pada masing-masing perda RTRW di setiap kabupaten telah terlihat upaya mitigasi bencana khususnya dalam perencanaan dan peraturan zonasi jaringan persampahan, jalur evakuasi bencana, kawasan hutan lindung, kawasan resapan air, kawasan perlindungan setempat 
kawasan rawan bencana, kawasan hutan produksi dan kawasan hutan rakyat. Namun demikian pada perda yang sama terdapat perencanaan dan peraturan zonasi yang berpotensi menghalangi mitigasi bencana yaitu kawasan budidaya pertanian, perikanan dan pemukiman. Jika pada kawasan yang menunjukkan adanya upaya pencegahan sedimentasi dan pembatasan pemukiman masyarakat di daerah rawan bencana banjir, tiga kawasan yang terakhir disebutkan berpotensi menambah sedimentasi dan penambahan pemukiman di daerah rawan bencana. Daerah sekitar Danau Tempe ditetapkan sebagai daerah perlindungan setempat, daerah resapan air dan daerah rawan bencana banjir yang aturan zonasinya mengarahkan pembatasan aktivitas pemukiman. Sebaliknya, kawasan sekitar Danau Tempe juga ditetapkan sebagai kawasan pertanian, perikanan dan pemukiman yang di dalam aturan zonasinya membolehkan adanya pemukiman. Disamping itu, kawasan pertanian, perikanan dan perumahan berpotensi menghasilkan sampah yang jika tidak dikelola dengan baik akan menambah sedimentasi Danau Tempe.

Ketiga kawasan budidaya tersebut dikatakan berpotensi menghambat mitigasi bencana karena belum bisa dipastikan bagaimana rencana detail dari peraturan daerah tersebut. Sebab dalam peraturan daerah, kawasan-kawasan tersebut hanya dituliskan berlokasi di sebagian wilayah kecamatan-kecamatan tertentu. Jika dalam rencana detail tata ruangnya tidak memperhatikan kawasan rawan bencana, kawasan sempadan sungai/sekitar danau, kawasan resapan air dan kelas lereng tanah serta tidak diatur secara ketat masalah persampahan dan metode penangkapan ikan seperti yang terjadi pada saat ini maka bisa dipastikan kawasan pertanian, perikanan dan pemukiman menjadi penghambat mitigasi bencana banjir luapan Danau Tempe. Pada saat penelitian dilakukan, rencana detail tata ruang belum disusun oleh masing-masing kabupaten.

Kondisi-kondisi yang diidentifikasi sebagai penyebab banjir danau 
tempe masih berlangsung hingga saat ini. Petani masih menanam tanaman pangan lahan kering di daerah pegunungan, nelayan masih menggunakan eceng gondok untuk menangkap ikan, petani masih membakar sampah sisa hasil pertaniannya, masyarakat masih membuang sampah di sungai atau di sekitar rumahnya, di daerah rawan bencana belum ada jalur evakuasi dan lain sebagainya. Praktis belum ada kondisi yang berubah pasca penetapan perda RTRW masing-masing kabupaten. Untuk kawasan hutan, sudah terlihat telah ada implementasi di lapangan. Hal tersebut disebabkan karena aktivitas penataan hutan telah dilaksanakan jauh sebelum penetapan rencana tata ruang wilayah kabupaten. Meskipun dalam pelaksanaanya masih terdapat kendala seperti yang terjadi di Kabupaten Soppeng.

\section{KERJASAMA ANTAR PEMERINTAH DAERAH}

Bencana banjir luapan Danau Tempe berdampak pada tiga kabupaten sehingga penting untuk dilakukan kerjasama antar pemerintah kabupaten dalam menanggulangi bencana banjir tersebut. Ada beberapa forum yang dibentuk untuk membahas kondisi Danau Tempe. Salah satu diantaranya dijelaskan oleh Kepala Dinas Kehutanan Kabupaten Wajo yaitu Forum Daerah Aliran Sungai (Forum DAS) Sulawesi Selatan yang melibatkan semua kabupaten di Sulawesi Selatan. Dalam Forum DAS tersebut, dibentuk satu sub forum yaitu DAS Peduli Danau Tempe. Pihak yang terlibat dalam Forum DAS tersebut yaitu kepala Dinas Kehutanan dan Perkebunan, Kepala Bappeda, Kepala Dinas Pertanian dan dinas-dinas lain yang berhubungan dengan pengelolaan DAS di Kabupaten Sidenreng Rappang, Wajo dan Soppeng. Beberapa programnya yaitu penghijauan dan reboisasi serta pembuatan kantong air. Forum DAS Sulawesi selatan dibentuk dengan Keputusan Gubernur Sulawesi Selatan No. 516/VII/Um/ 2005 tentang Pembentukan Forum Koordinasi Pengelolaan DAS 


\section{Provinsi Sulawesi Selatan.}

Dilihat dari fungsinya, Forum DAS ini tidak dapat dikategorikan sebagai kerjasama antar pemerintah daerah, meskipun di dalamnya terdapat beberapa unsur satuan kerja pemerintah daerah. Forum DAS hanya berfungsi mempertemukan berbagai pihak dalam memberikan masukan pengelolaan DAS. Pengambilan keputusan tetap dikembalikan pada pemerintah, baik itu pemerintah kabupaten, provinsi, maupun pemerintah pusat.

Selain forum DAS, Badan Lingkungan Hidup Daerah Provinsi Sulawesi Selatan juga melakukan pertemuan lintas kabupaten untuk memberikan masukan dalam rangka penyusunan buku pedoman penyelamatan Danau Tempe. Masing-masing BLHD Kabupaten yang terkait dengan Danau Tempe baik yang berada di hulu sungai maupun di hilir diundang untuk memberikan masukan terkait penyusunan buku pedoman tersebut. Namun seperti halnya Forum DAS, pertemuan tersebut juga tidak dapat dianggap sebagai kerjasama antar pemerintah daerah.

Dalam hal penataan ruang, juga belum ditemukan adanya kerjasama antar pemerintah daerah. Hasil wawancara dengan Dinas Tata Ruang Kabupaten Wajo, DPU Kabupaten Soppeng dan Bappeda Kabupaten Sidenreng Rappang menunjukkan bahwa tidak ada kerjasama dalam hal penataan ruang. Bahkan dalam hal penetapan batas antar kabupaten sekalipun, tidak dilakukan koordinasi antar pemerintah daerah yang membidangi penataan ruang maupun pengembangan wilayah.

Salah satu hal yang menjadi penyebab tidak adanya kerjasama antar pemerintah daerah adalah karena kebijakan-kebijakan yang sifatnya lintas kabupaten menjadi kewenangan Pemerintah Provinsi. Dalam beberapa kasus bahkan menjadi kewenangan pemerintah pusat. Wilayah Sungai Walanae-Cenranae yang merupakan sungai yang melalui beberapa kabupaten misalnya, telah menjadi kewenangan pemerintah pusat. Demikian pula Danau Tempe yang 
berada di tiga kabupaten, kewenangan dalam hal pelestarian lingkungannya telah menjadi kewenangan pemerintah provinsi melalui penetapan Danau Tempe sebagai kawasan strategis provinsi.

\section{KESIMPULAN}

Upaya mitigasi nonstruktural bencana banjir luapan Danau Tempe melalui penataan ruang telah terlihat pada beberapa pasal dalam peraturan daerah rencana tata ruang wilayah di Kabupaten Sidenreng Rappang, Soppeng dan Wajo. Penetapan jaringan sistem persampahan, jalur dan ruang evakuasi bencana, kawasan hutan lindung, kawasan resapan air, kawasan perlindungan setempat, kawasan rawan bencana, kawasan hutan produksi dan kawasan hutan rakyat beserta dengan aturan pengendalian pemanfaatan ruangnya dapat dilihat sebagai bagian dari mitigasi nonstruktural bencana banjir. Pada peraturan yang sama terdapat perencanaan kawasan budidaya pertanian, perikanan dan perumahan yang berpotensi menjadi penghambat mitigasi bencana banjir. Mitigasi nonstruktural bencana banjir sebagaimana yang tercantum dalam peraturan daerah rencana tata ruang belum dilaksanakan secara optimal karena belum adanya rencana detail tata ruang di masingmasing kabupaten. Selain itu, faktor persepsi dan ketangguhan masyarakat dapat menyebabkan mitigasi nonstruktural bencana banjir luapan Danau Tempe belum menjadi prioritas pemerintah.

Dalam penelitian ini juga belum ditemukan ada kerjasama antar pemerintah Kabupaten Sidenreng Rappang, Soppeng dan Wajo dalam hal mitigasi nonstruktural bencana banjir luapan Danau Tempe melalui penataan ruang. Penyebabnya adalah karena urusan pemerintahan lintas kabupaten dikelola langsung oleh pemerintah provinsi atau pemerintah pusat.

\section{DAFTAR PUSTAKA}

BUKU

Badan Kesatuan Bangsa dan Perlindungan Masyarakat Kabupaten Soppeng. 2013. 
Laporan Hasil Pemantauan Bencana Alam Banjir di Wilayah Kabupaten Soppeng pada Hari Senin Tanggal 15 Juli 2013. Watang Soppeng.

Benson, Charlotte, John Twigg. 2007. Perangkat untuk Mengarusutamakan Pengurangan

Resiko Bencana: Catatan Panduan bagi Lembaga-Lembaga yang Bergerak dalam

Bidang Pembangunan. Yogyakarta: Cyrcle Indonesia.

BP DAS Jeneberang Walanae. 2013. Laporan Banjir di Wilayah DAS Jeneberang Walanae

Tahun 2013. Makassar.

Departemen Kehutanan Republik Indonesia. 2008. Kerangka Kinerja Pengelolaan Daerah Aliran Sungai di Indonesia. Jakarta.

Keputusan Menteri Kehutanan Republik Indonesia Nomor SK.434/Menhut-II/2009

tentang Penunjukan Kawasan Hutan dan Konservasi Perairan di Wilayah Provinsi

Sulawesi Selatan

Kodoatie, Robert J dan Roestam Syarif. 2010. Tata Ruang Air. Yogyakarta: Penerbit Andi. Kodoatie, Robert J. dan Sugiyanto. 2002. Banjir: Beberapa Penyebab dan Metode

Pengendaliannya dalam Perspektif Lingkungan. Yogyakarta: Pustaka Pelajar.

Kodoatie, Robert J. 2008. Analisa Ancaman Bencana Hydrometeorologis di Indonesia,

dalam Upaya Organisasi Masyarakat Sipil dalam Pengurangan Resiko Bencana, Adi

Nugroho (Peny). Yogyakarta: Yayasan SHEEP Indonesia.

Nawawi, Hadari \& Mimi Martini.1996. Penelitian Terapan, cetakan kedua, Yogyakarta:

Gadjah Mada University Press.

Noor, Juliansyah. 2012. Metodologi Penelitian: Skripsi, Tesis, Disertasi dan Karya IImiah, cetakan kedua. Jakarta: Kencana.

Nurjanah dkk. 2012. Manajemen Bencana. Bandung: Alfabeta.

Peraturan Daerah Kabupaten Nomor 5 Tahun 2012 tentang Rencana Tata Ruang Wilayah Kabupten Tahun 2012-2032

Peraturan Daerah Kabupaten Soppeng Nomor 8 Tahun 2012 tentang Rencana Tata Ruang Wilayah Kabupaten Soppeng Tahun 2012-2032

Peraturan Daerah Kabupaten Wajo Nomor 12 Tahun 2012 tentang Rencana Tata Ruang Wilayah Kabupaten Wajo Tahun 2012-2032

Peraturan Daerah Provinsi Sulawesi Selatan Nomor 5 Tahun 2012 tentang Rencana Tata

Ruang Wilayah Provinsi Sulawesi Selatan Tahun 2012-2032

Peraturan Menteri Dalam Negeri Nomor 22 Tahun 2009 tentang Petunjuk Teknis Tata

Cara Kerja Sama Antar Daerah

Peraturan Pemerintah Republik Indonesia Nomor 50 Tahun 2007 tentang Tata Cara Kerjasama Antar Daerah

Peraturan Pemerintah Republik Indonesia Nomor 26 Tahun 2008 tentang Rencana Tata Ruang Nasional

Peraturan Pemerintah Republik Indonesia Nomor 15 Tahun 2010 tentang Penyelenggaraan Penataan Ruang

Priambodo, S. Arie. 2009. Panduan Praktis Menghadapi Bencana. Yogyakarta: Kanisius. Rostin, \& Rahael Kimbal. 2012. Teknik Pengumpulan Data Kualitatif dalam Desain Penelitian: Pendekatan Kualitatif. Diaspora Tim, Malang: Insan Muamalah. 
Salim, Agus, \& Ali Formen. 2006. Pengantar Berpikir Kualitatif (Menuju Objektifitas Penelitian Sosial di Indonesia) dalam Teori dan Paradigma Penelitian Sosial, Edisi Kedua, Agus Salim (peny). Yogyakarta: Tiara Wacana.

Sastrodihardjo, Siswoko. 2010. Upaya Mengatasi Masalah Banjir Secara Menyeluruh, Jakarta: Yayasan Badan Penerbit Pekerjaan Umum.

Schwab, Anna K. Katherine Eschelbach, \& David J. Browner. 2007. Hazard Mitigation and Preparedness. United States: Wiley.

Sudibyakto dkk. 2012. Menuju Masyarakat Tangguh Bencana: Tinjauan dari Fenomena Multi-Bencana Indonesia dalam Konstruksi Masyarakat Tangguh Bencana, Agus Indiyanto \& Arqom Kuswanjono (eds). Bandung: Mizan.

Sudibyakto. 2011. Manajemen Bencana di Indonesia Ke Mana?. Yogyakarta: Gadjah Mada University Press.

Sugiyono. 2012. Metode Penelitian Kuantitatif dan Kualitatif, Cetakan ke 17, Bandung: Alfabeta.

Sukandarrumidi. 2010. Bencana Alam \& Bencana Anthropogene: Petunjuk Praktis untuk Menyelamatkan diri dan Lingkungan. Yogyakarta: Kanisius.

Susanto, A.B. 2006. Disaster Management di Negeri Rawan Bencana, Jakarta: Aksara Grafika Pratama.

Triutomo, Sugeng, B. Wisnu Widjaya, Mohd. Robi Amri (eds.). 2007. Pengenalan Karakteristik Bencana dan Upaya Mitigasinya di Indonesia, Edisi II,Jakarta: Direktorat Mitigasi, Lakhar BAKORNAS PB.

Undang-Undang Republik Indonesia Nomor 24 Tahun 2007 tentang Penanggulangan Bencana

Undang-Undang Nomor 18 Tahun 2013 tentang Pencegahan dan Pemberantasan Perusakan Hutan

UNDP, Modul Mitigasi Bencana, Edisi Kedua, 1994

JURNAL

Hasnawir. 2012. "Ambang Batas Curah Hujan untuk Bencana Sedimen di Kaldera Bawakaraeng, Sulawesi Selatan". Jurnal Penanggulangan Bencana Volume 3 Nomor 1, Juni 2012.

Maarif, Syamsul. 2010. "Bencana dan Penanggulangannya". Jurnal Dialog Penanggulangan Bencana. Volume 1 Nomor 1 Oktober 2010.

Permana, Raden Cecep Eka dkk. 2011. "Kearifan Lokal tentang Mitigasi Bencana Pada Masyarakat Baduy". Makara, Sosial Humaniora, Vol. 15, No. 1, Juli 2011.

Sarasati, Wirasti. "Praktek Kearifan Lokal Dalam Pengurangan Resiko Bencana Alam". Jurnal Perencanaan Wilayah dan Kota B SAPPK V4N2

WEBSITE:

Badan Nasional Penanggulangan Bencana, Info Bencana Edisi September 2013, Jakarta, 2013 diakses dari http://www.bnpb.go.id/ tanggal 31 Oktober 2013 pukul 05.30. 
Data \& Informasi Bencana Indonesia BNPB, Perbandingan Jumlah Kejadian Bencana per Jenis Bencana 1815-3013, Jakarta, 2013 diakses dari http://dibi.bnpb.go.id tanggal 31 Oktober 2013 pukul 08.29.

Data \& Informasi Bencana Indonesia BNPB, Sebaran Kejadian Bencana dan Korban Meninggal per Jenis Bencana 1815-3013, Jakarta, 2013 diakses dari http:// dibi.bnpb.go.id tanggal 31 Oktober 2013 pukul 08.29. 